\title{
Galli gigeriae endothelium corneum: its intestinal barrier protective activity in vitro and chemical composition
}

\author{
Shanshan Li ${ }^{1}$, Meng Zheng ${ }^{1}$, Zhentang Zhang ${ }^{1}$, Hengying Peng ${ }^{1}$, Wenling Dai ${ }^{1}$ and Jihua Liu ${ }^{1,2^{*}}$ (D)
}

\begin{abstract}
Background: Galli gigeriae endothelium corneum (GGEC) has been effectively used for centuries for the treatment of functional dyspepsia (FD) in clinical practice in Asian countries. However, its potential mechanism and chemical composition remains undertermined.

Methods: In this study, the chemical profile of GGEC ethyl acetate extract (EAE) was evaluated by HPLC-Q-TOF-MS/ MS. The effects of EAE on intestinal barrier function and inflammation were investigated in IEC-6 cells and RAW264.7 cells.

Results: The results showed that 33 compounds were tentatively identified, including 12 soy isoflavones, 7 bile acids for the first time in EAE. EAE significantly reinforced intestinal barrier function via increasing the tight junction protein levels of ZO- 1 and Occludin, reducing the mRNA expression levels of interleukin (IL)- $1 \beta$ and IL-6 in tumor necrosis factor alpha (TNF-a)-challenged IEC- 6 cells. The scratch wound assay showed that EAE accelerated wound healing of IEC-6 cells. EAE evidently reduced the level of $N O$ in a dose-dependent manner with an $I_{50}$ value of $18.12 \mu \mathrm{g} / \mathrm{mL}$, and the mRNA expression of TNF- $a$, IL-1 $\beta, I L-6$, iNOS and COX-2 in LPS-treated RAW264.7 cells.

Conclusion: This study revealed the intestinal barrier protective effects and chemical profile of GGEC, and the results indicated that GGEC strengthened the intestinal barrier by up-regulating protein expression of tight junctions and limiting inflammatory responses.
\end{abstract}

Keywords: Galli gigeriae endothelium corneum, HPLC-QTOF-MS/MS, Identification, Anti-inflammatory, Wound healing, Gastrointestinal barrier

\section{Background}

Intestinal epithelial cells (IECs) play a vital role in digestion and nutrient absorption and prevent harmful agents from entering the body acting as a physical barrier to maintain intestinal homeostasis [1]. The integrity of the intestinal barrier is closely related to intestinal health, and it is regulated by the interaction of various barrier

\footnotetext{
*Correspondence: liujihua@cpu.edu.cn

1 Jiangsu Key Laboratory of TCM Evaluation and Translational Research,

School of Traditional Chinese Pharmacy, China Pharmaceutical University, Nanjing 211198, People's Republic of China

Full list of author information is available at the end of the article
}

components, such as the mucous layer, antibacterial peptides, and tight junctions (TJs) [2]. Therefore, maintaining a proper TJ expression level is widely considered as an effective therapeutics target for the treatment of intestinal diseases [3].

The intestinal epithelium can be injured by several factors such as toxic luminal substances, inflammation, and oxidative stress [4]. After injury, the balance between anti- and pro-inflammatory cytokines becomes disrupted and pro-inflammatory cytokine secretion is increased [5]. Recent studies have indicated that inhibition of cytokines induces increase in intestinal permeability, resulting in an important protective effect against intestinal epithelial 
damage and intestinal inflammation [6]. Therefore, it is necessary to improve gut health through suppressing unnecessary inflammatory responses [7].

Galli gigeriae endothelium corneum (GGEC), the dried inner wall of the Gallus gallus domesticus Brisson as a chicken by-product, is described in the Chinese pharmacopoeia as a well-known traditional Chinese drug and an edible food [8]. GGEC is widely used in Asian countries in clinical practice for the treatment of diarrhea, dyspepsia, infantile malnutrition, and mammary gland proliferation, especially in the treatment of children with indigestion [9]. In recent years, there have been studies on the chemical composition of GGEC, which have mainly focused on macromolecules such as proteins and polysaccharides [10]. However, information on the micro-molecules of GGEC is still limited.

Studies have revealed that injured intestinal barrier [11] and over-inflammation are the characteristics of gastrointestinal disorders [12]. Therefore, here, we explored the effects of GGEC on the intestinal epithelial barrier as well as its chemical composition aiming to provide a theoretical basis for further research on the clinical use of GGEC for improving gut health.

\section{Materials and methods}

\section{Chemicals and reagents}

Rat intestinal epithelial (IEC-6) cells and RAW 264.7 murine macrophage cell line (ATCC, USA) were cultured in DMEM supplemented with $10 \%$ fetal bovine serum (FBS), 100 units $/ \mathrm{mL}$ penicillin, $100 \mu \mathrm{g} / \mathrm{mL}$ streptomycin and 0.1 unit $/ \mathrm{mL}$ human insulin (for IEC-6 cells) and maintained in a carbon dioxide incubator (Thermo Fisher Scientific, USA) with a humidified atmosphere of $95 \%$ air and $5 \% \mathrm{CO}_{2}$ at $37^{\circ} \mathrm{C}$.

\section{Preparation of samples}

GGEC was collected from the Traditional Chinese Medicine Market (Bozhou, China), and identified and retained at Jiangsu Key Laboratory of TCM Evaluation and Translational Research, China Pharmaceutical University (Nanjing, China). GGEC ethyl acetate extract (EAE) was prepared as follows. The powered GGEC $(5 \mathrm{~kg})$ was extracted twice with $70 \%$ ethanol $(\mathrm{v} / \mathrm{v})$ in a hot water bath, each time for $1 \mathrm{~h}$. Ethanol was removed with a rotary evaporator and part of the $70 \%$ extract was suspended in water and extracted successively with petroleum ether and ethyl acetate, respectively. After evaporation of the solvent in vacuum, the ethyl acetate fraction (EAE, $50 \mathrm{~g}$ ) was obtained. The EAE was dissolved in dimethyl sulfoxide (DMSO) for used as a stock solution $(10 \mathrm{mg} / \mathrm{mL})$, which was diluted in the medium and added to the cells at different concentrations (The final concentration of DMSO in medium was no more than $0.1 \%)$.

\section{Chemical identification HPLC-QTOF-MS/MS analysis}

The chemical analysis of the EAE was performed on an Agilent 1260 series HPLC system (Agilent Technologies, USA). Sample separation was achieved on an Agilent ZORBAX SB- $\mathrm{C}_{18}$ column $(4.6 \mathrm{~mm} \times 250 \mathrm{~mm}, 5 \mu \mathrm{m})$ with a constant flow rate of $1.0 \mathrm{~mL} / \mathrm{min}$ at $30{ }^{\circ} \mathrm{C}$. The mobile phase was composed of water $(0.1 \%$ formic acid, A) and acetonitrile (B) using gradient elution. The gradients were operated as follows: $0-60 \mathrm{~min}, 10-90 \% \mathrm{~B}$; 60-62 min, $90-10 \%$ B; $62-70 \mathrm{~min}, 10 \% \mathrm{~B}$. The sample volume injected was set at $10 \mu \mathrm{L}$. The peaks were monitored at 254 and $280 \mathrm{~nm}$.

An Agilent 6530 Q-TOF mass spectrometer (Agilent Technologies, USA) equipped with an electrospray ionization (ESI) source was used to perform the MS analysis. The acquisition parameters were as follows: drying gas (N2) flow rate, $10.0 \mathrm{~L} / \mathrm{min}$; drying gas temperature, $350{ }^{\circ} \mathrm{C}$; nebulizer, 35 psig; capillary, $3500 \mathrm{~V}$; OCTRFV, $750 \mathrm{~V}$; and fragmentor voltage, $120 \mathrm{~V}$. The mass range was recorded from $\mathrm{m} / z 50$ to 1500 in positive and negative modes with collision energy (CE) from 10 to $50 \mathrm{eV}$. Peaks were detected by positive and negative ionization mode of MS and MS/MS detection. All operations, data acquisition and analysis were controlled by Agilent Mass Hunter Workstation software version B.07.00.

\section{Compounds identification}

The obtained HPLC-QTOF-MS/MS data were interpreted with the authentic reference standards or with its structural analogues, analyzed in identical experimental conditions to compare their chromatographic and mass spectral profiles and the literature $[13,14]$.

\section{Assessment of intestinal barrier function}

The intestinal barrier function was evaluated as previously reported [15]. Cells were incubated with EAE (0.1, 0.03 , and $0.01 \mathrm{mg} / \mathrm{mL})$ for $1 \mathrm{~h}$, then TNF- $\alpha(50 \mathrm{ng} / \mathrm{mL})$ was added to the apical side for $24 \mathrm{~h}$. The transepithelial electrical resistance (TEER) was monitored using a Millicell-ERS volt-ohmmeter (Millipore, USA). FD-4 (SigmaAldrich) with a final concentration of $1 \mathrm{mg} / \mathrm{mL}$ dissolved in Krebs was added to the apical side of the insets and $600 \mu \mathrm{L}$ Krebs was added to the basolateral side [16]. The basolateral medium was taken after $1 \mathrm{~h}$ of incubation. The diffused fluorescent tracer was then measured by fluorometry (excitation, $485 \mathrm{~nm}$; emission, $528 \mathrm{~nm}$ ). The data are presented as a percentage of the control group [17]. 


\section{Western blotting analysis}

Cells were rinsed with ice-cold PBS buffer thrice and lysed with RIPA lysis buffercontaining $1 \mathrm{mM}$ PMSF on ice for $30 \mathrm{~min}$. The cell debris was subsequently removed by centrifugation at $12000 \mathrm{~g}$ for $10 \mathrm{~min}$ at $4{ }^{\circ} \mathrm{C}$. Then the supernatant was collected for analysis by adding using $5 \times$ SDS loading buffer containing 7\% $\beta$-mercaptoethanol. Equal amounts of protein samples were separated by $10 \%$ (v/v) SDS-PAGE and transferred onto PVDF membranes $(0.22 \mu \mathrm{m}$, Millipore, USA). After blocking with 5\% BSA at room temperature for $2 \mathrm{~h}$, the membranes were incubated with the corresponding primary anti-ZO-1 (1:1000; Proteintech, USA), anti-GAPDH (1:8000; Sigma, USA) and anti-Occludin (1:1000; Proteintech, USA) antibodies at $4{ }^{\circ} \mathrm{C}$ overnight. The membranes were then incubated with HRP-conjugated anti-rabbit IgG (1:4000; Cell Signaling Technology, USA) secondary antibodies for $2 \mathrm{~h}$ at room temperature, and the immunoreactive protein bands were visualized using ECL detection reagents (Bio-Rad, USA). The intensity of protein bands was quantitated using an Image Lab analysis software and normalized to GAPDH.

\section{Anti-inflammatory effects Cell viability and nitric oxide (NO) inhibition assay}

RAW264.7 cells were plated into a 96-well plate at a density of $1 \times 10^{4} /$ well in $200 \mu \mathrm{L}$ of DMEM medium and incubated overnight. Then the medium was replaced with various concentrations of EAE including 0.1, 0.03, and $0.01 \mathrm{mg} / \mathrm{mL}$ and incubated for another $24 \mathrm{~h}$. Cell culture media were collected, following the measurement of the nitrite level using Griess reaction assay. Cytotoxicity of EAE was evaluated by MTT assay. The percentage of cell viability was calculated as a percentage of the control. The $\mathrm{IC}_{50}$ of NO inhibition rate was calculated using GraphPad (GraphPad Software, San Diego, CA, USA).

\section{Real-time quantitative reverse transcription polymerase chain reaction (qRT-PCR)}

RAW 264.7 cells /IEC-6 cells were cultured at $1 \times 10^{6}$ cells/well in 6-well plates and pretreated in the absence or presence $(0.1,0.03$, and $0.01 \mathrm{mg} / \mathrm{mL})$ of EAE for $1 \mathrm{~h}$, prior to being untreated or stimulated with LPS $(1 \mu \mathrm{g} / \mathrm{mL})$ or TNF- $\alpha(50 \mathrm{ng} / \mathrm{mL})$ for $24 \mathrm{~h}$. The cells were harvested, and total RNA was extracted using TRI reagent solution (TransGen Biotech,Beijing, China). The following primers were used for qPCR: GAPDH, forward, $5^{\prime}$-CAGGGC TGCCTTCTCTTGTG- $3^{\prime}$ and reverse, $5^{\prime}$-GATGGTGAT GGGTTTCCCGT-3'; IL-6, forward, 5'-AATCTGCTC TGGTCTTCTGG- $3^{\prime}$ and reverse: $5^{\prime}$-GATGAGTTGGAT GGTCTTGG-3'; IL-1 $\beta$, forward, 5'-CCAGGATGAGGA CCCAAGCA- $3^{\prime}$ and reverse, ${ }^{\prime}$-TCCCGACCATTGCTG
TTTCC-3'; GAPDH (mice), forward, 5'-CAGTGGCAA AGTGGAGATTG- $3^{\prime}$ and reverse, ${ }^{\prime}$-GTTGTCATGGAT GACCTTGG-3'; IL-6 (mice), forward, 5'-GCTACCTGG AGTACATGAAG- $3^{\prime}$ and reverse, $5^{\prime}$-CTGTGACTCCAG CTTATCTG-3'; IL-1 $\beta$ (mice), forward, 5'-ATGAGGACA TGAGCACCTTC- ${ }^{\prime}$ and reverse, ${ }^{\prime}$-CATTGAGGTGGA GAGCTTTC-3'; TNF- $\alpha$ (mice), forward, 5'-CTCAGA TCATCTTCTCAAAATTCGAGTGACA- $3^{\prime}$ and reverse, 5'-CTTCACAGAGCAATGACTCCAAAGT-3'; iNOS (mice), forward, 5'-CTCAGATCATCTTCTCAAAAT TCGAGTGACA- $3^{\prime}$ and reverse, $5^{\prime}$-CTTCACAGAGCA ATGACTCCAAAGT-3'; COX-2 (mice), forward: $5^{\prime}$-ATG GTCAGTAGACTTTTACA- ${ }^{\prime}$ and reverse: 5'-GGAGAG $^{\prime}$ ACTATCAAGATAGT-3'

\section{Wound healing assay}

IEC-6 cells were seeded into six-well plates at a density of $5 \times 10^{5}$ cells/well, and were cultured in fresh cultured media to $90 \%$ confluence. After being washed with PBS, the medium was replaced with DMEM-1\% FBS. EAE (0.1, 0.03 , and $0.01 \mathrm{mg} / \mathrm{mL}$ ) was added to the corresponding chambers. The cell migration images were photographed at 0 and $8 \mathrm{~h}$ following scraping [5]. The wound scratches were measured using Image J software. Three to four different fields were visualized and photographed with an optical microscope at $100 \times$ magnification (Olympus IX53, Tokyo, Japan). The migration rates were calculated using the following formula: [(the initial width) - (the width after $8 \mathrm{~h}$ of culturing)]/(the initial width) $\times 100 \%$.

\section{Statistical analysis}

Values are presented as mean \pm SD. Differences among groups were analyzed by one-way ANOVA with Dunnett's test using GraphPad 5.0 software. The value of $p<0.05$ was considered statistically significant.

\section{Results}

Identification of constituents in EAE of GGEC

A total of 33 compounds were identified from EAE by HPLC-Q-TOF-MS/MS in the positive/ negative ion mode (Fig. 1). The retention time and mass spectrometry information of each chemical constituent of GGEC were detected as shown in Table 1. Thirty-three compounds including 12 soy isoflavones, 7 bile acids, 4 nucleic bases and nucleosides and 10 other compounds were identified. Except the amino acids, these compounds were reported here in GGEC for the first time.

\section{Nucleic bases and nucleosides}

Nucleobases are nitrogen containing biological compounds linked to a sugar within nucleosides making up the basic building blocks of DNA and RNA. Nucleobases and nucleosides play important roles in the process of 


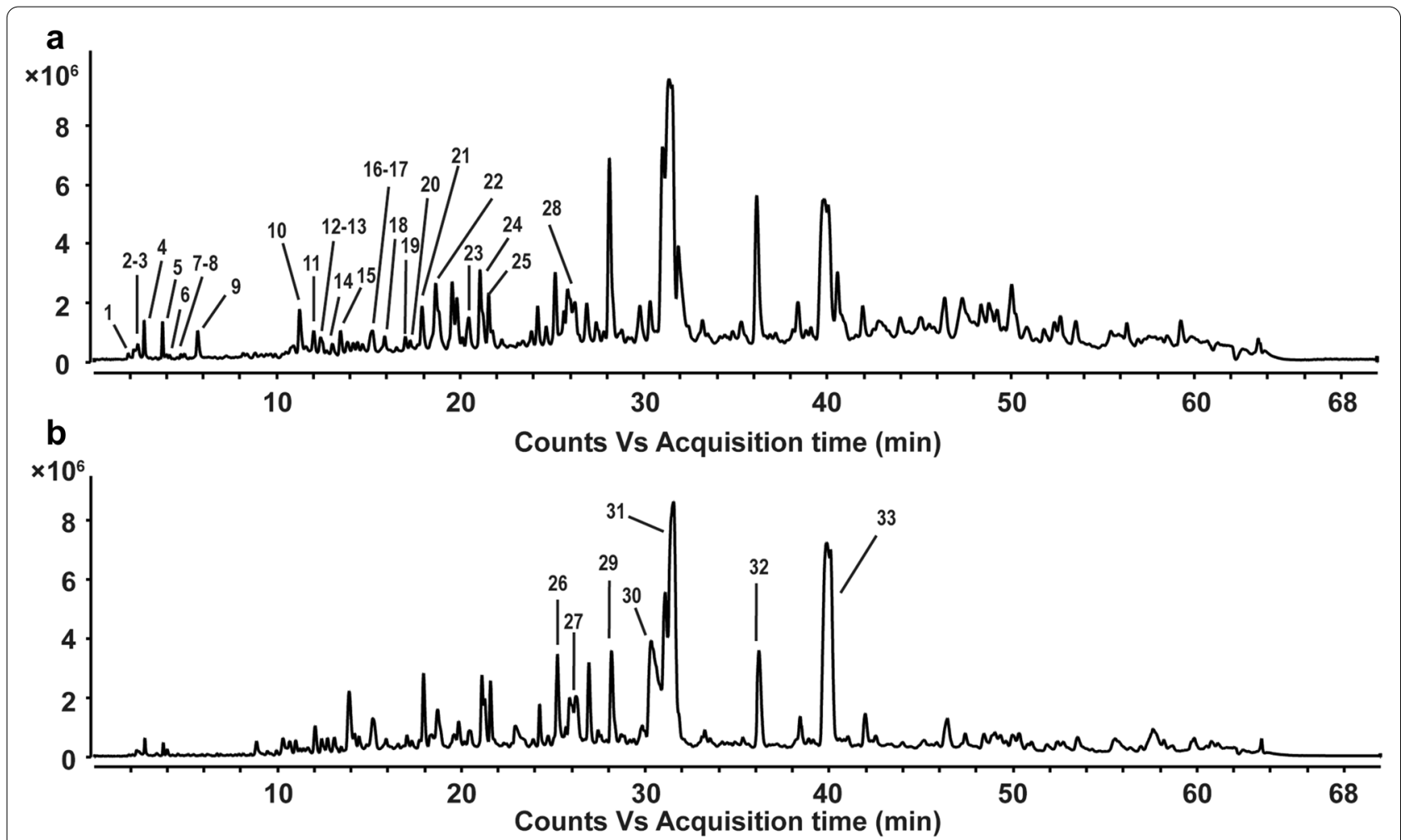

Fig. 1 Total ion chromatograms (TIC) in the positive-ion mode (a) and negative-ion mode (b) from HPLC-QTOF-MS/MS of EAE. EAE: Galli gigeriae endothelium corneum ethyl acetate extract

lives [18]. The most common fragmentation process for nucleic bases is the loss of $\mathrm{H}_{2} \mathrm{O}$ and/or $\mathrm{NH}_{3}$, followed by the removal of $\mathrm{HCN}$ or $\mathrm{CO}$. Compound 2 was identified as adenine with $m / z^{+} 136.0611$ and diagnostic fragmentation $m / z^{+} 119.0342[\mathrm{M}+\mathrm{H}-\mathrm{NH} 3]^{+}$. Similarly, compound 5 had $m / z^{+} 268.1025$ with $\mathrm{C}_{10} \mathrm{H}_{13} \mathrm{~N}_{5} \mathrm{O}_{4}$ was adenosine [19]. The observed $m / z^{+} 152.0559$ of compound 3 with formula $\mathrm{C}_{5} \mathrm{H}_{5} \mathrm{~N}_{5} \mathrm{O}$ was identified as guanine [20]. Compound 4 was identified as hypoxanthine with formula $\mathrm{C}_{5} \mathrm{H}_{4} \mathrm{~N}_{4} \mathrm{O}$ as it produced fragment ions at $m / z^{+} 119.0345$ and 110.0354 .

\section{Amino acids and peptides}

Although various free amino acids can be detected in GGEC water extract, in this part only few of them can be detected maybe due to their hydrophobicity. Compound 8 displayed a molecule at $m / z^{+} 132.1014$ with the molecular formula $\mathrm{C}_{6} \mathrm{H}_{13} \mathrm{NO}_{2}$, which was presumed tentatively as leucine or isoleucine [21]. In addition, a cyclodipeptide with the molecular formula $\mathrm{C}_{11} \mathrm{H}_{18} \mathrm{~N}_{2} \mathrm{O}_{2}$ was presumed as $L, L$-cyclo(leucylprolyl) [22].

\section{Isoflavones}

Isoflavones were firstly identified from GGEC. As many as 12 isoflavones were identified by HPLC-Q-TOF-MS/
MS in this study. Among them, compounds 24, 25, 28 showed mass spectral responses for parent ions that lead to the formation of isoflavone aglycone fragment ions at $m / z^{+} 255.0636$ for daidzein, $m / z^{+} 285.0739$ for glycitein, and $m / z^{+} 271.0584$ for genistein [23]. Compounds $11,12,17$ were unambiguously identified as daidzin $\left(m / z^{+} 417.1148\right)$, glycitin $\left(m / z^{+} 447.1249\right)$, genistin $\left(m / z^{+} 433.1103\right)$ with observed the loss of 162 .

The remaining compounds could be tentatively assigned according to the literature from the accurate mass data [24]. Compounds 16 and 19 had $m / z^{+}$ 503.1184 and 459.1261, and the chemical formula were $\mathrm{C}_{24} \mathrm{H}_{22} \mathrm{O}_{12}$ and $\mathrm{C}_{23} \mathrm{H}_{22} \mathrm{O}_{10}$, respectively. They were presumed to be $6^{\prime \prime}-O$-malonyldaidzin and $6^{\prime \prime}-O$-acetyldaidzin according to the fragmentation patterns. Similarly, compounds 13, 21 and $23 \mathrm{had} m / z^{+} 447.0922,519.1133$ and 475.1235 with the formula $\mathrm{C}_{21} \mathrm{H}_{18} \mathrm{O}_{11}, \mathrm{C}_{24} \mathrm{H}_{22} \mathrm{O}_{13}$ and $\mathrm{C}_{23} \mathrm{H}_{22} \mathrm{O}_{11}$ were presumed as genistein-O-glucuronide, $6^{\prime \prime}$-malnoylgenistin and $6^{\prime \prime}$-O-acetylgenistin, respectively. Compound 20 was presumed to be $6^{\prime \prime}$-O-acetylglycitin as with its formula $\mathrm{C}_{24} \mathrm{H}_{24} \mathrm{O}_{11}$. These six compounds were deduced to be generated based on the nuclei. 
Table 1 The chromatographic and mass spectrometric data of galli gigeriae endothelium corneum ethyl acetate extract using HPLC-QTOF-MS/MS

\begin{tabular}{|c|c|c|c|c|c|c|c|c|c|}
\hline \multirow{2}{*}{ 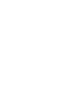 } & \multirow[t]{2}{*}{ RT } & \multirow{2}{*}{$\begin{array}{l}\text { Precusor } \\
\text { ion (amu) } \\
M\end{array}$} & \multirow[t]{2}{*}{ Selective ion } & \multicolumn{2}{|l|}{$m / z$} & \multirow[t]{2}{*}{ Mass error (ppm) } & \multirow[t]{2}{*}{ Formula } & \multirow{2}{*}{$\begin{array}{l}\text { Observed diagnostic } \\
\text { CID fragment ions }\end{array}$} & \multirow[t]{2}{*}{ Identification } \\
\hline & & & & Measured & Calculated & & & & \\
\hline 1 & 2.28 & 113.0589 & {$[\mathrm{M}+\mathrm{H}]^{+}$} & 114.0664 & 114.0662 & -1.87 & $\mathrm{C}_{4} \mathrm{H}_{7} \mathrm{~N}_{3} \mathrm{O}$ & 72.0562 & Creatinine [19] \\
\hline 2 & 2.42 & 135.0538 & {$[\mathrm{M}+\mathrm{H}]^{+}$} & 136.0611 & 136.0604 & -3.45 & $\mathrm{C}_{5} \mathrm{H}_{5} \mathrm{~N}_{5}$ & $\begin{array}{l}119.0342,92.0241 \\
65.0132\end{array}$ & Adenine [19] \\
\hline 3 & 2.52 & 151.0494 & {$[\mathrm{M}+\mathrm{H}]^{+}$} & 152.0559 & 152.0567 & 1.78 & $\mathrm{C}_{5} \mathrm{H}_{5} \mathrm{~N}_{5} \mathrm{O}$ & $\begin{array}{l}\text { 135.0291, 110.0347, } \\
80.0259\end{array}$ & Guanine [20] \\
\hline 4 & 2.77 & 136.0377 & {$[\mathrm{M}+\mathrm{H}]^{+}$} & 137.0450 & 137.0458 & 2.79 & $\mathrm{C}_{5} \mathrm{H}_{4} \mathrm{~N}_{4} \mathrm{O}$ & $\begin{array}{l}119.0345,110.0354 \\
94.0384\end{array}$ & Hypoxanthine [20] \\
\hline 5 & 3.77 & 267.0952 & {$[\mathrm{M}+\mathrm{H}]^{+}$} & 268.1025 & 268.1040 & 3.73 & $\mathrm{C}_{10} \mathrm{H}_{13} \mathrm{~N}_{5} \mathrm{O}_{4}$ & 136.0618 & Adenosine [20] \\
\hline 6 & 3.92 & 122.048 & {$[\mathrm{M}+\mathrm{H}]^{+}$} & 123.057 & 123.0553 & -1.02 & $\mathrm{C}_{6} \mathrm{H}_{6} \mathrm{~N}_{2} \mathrm{O}$ & $\begin{array}{l}109.0464,80.0465 \\
53.0366\end{array}$ & Niacinamide [19] \\
\hline 7 & 4.96 & 168.0896 & {$[\mathrm{M}+\mathrm{H}]^{+}$} & 169.0969 & 169.0972 & -0.27 & $\mathrm{C}_{8} \mathrm{H}_{12} \mathrm{~N}_{2} \mathrm{O}_{2}$ & $98.0600,70.0656$ & Pyridoxamine [19] \\
\hline 8 & 5.18 & 131.0946 & {$[\mathrm{M}+\mathrm{H}]^{+}$} & 132.1014 & 132.1019 & 1.85 & $\mathrm{C}_{6} \mathrm{H}_{13} \mathrm{NO}_{2}$ & $\begin{array}{l}86.0965,69.0701 \\
57.0580,44.0500\end{array}$ & Leucine/isoleucine [21] \\
\hline 9 & 5.97 & 129.0574 & {$[\mathrm{M}+\mathrm{H}]^{+}$} & 130.0647 & 130.0651 & 3.3 & $\mathrm{C}_{9} \mathrm{H}_{7} \mathrm{~N}$ & $103.0546,77.0385$ & Isoquinoline [20] \\
\hline 10 & 11.16 & 173.1052 & {$[\mathrm{M}+\mathrm{H}]^{+}$} & 174.1146 & 174.1125 & -2.31 & $\mathrm{C}_{8} \mathrm{H}_{15} \mathrm{NO}_{3}$ & $90.0492,57.0671$ & Acly-glycine [21] \\
\hline 11 & 12.00 & 416.1075 & {$[\mathrm{M}+\mathrm{H}]^{+}$} & 417.1148 & 417.1180 & 0.71 & $\mathrm{C}_{21} \mathrm{H}_{20} \mathrm{O}_{9}$ & 255.0627 & Daidzin [23] \\
\hline 12 & 12.36 & 446.1176 & {$[\mathrm{M}+\mathrm{H}]^{+}$} & 447.1249 & 447.1286 & 2.3 & $\mathrm{C}_{22} \mathrm{H}_{22} \mathrm{O}_{10}$ & 285.0751 & Glycitin [23] \\
\hline 13 & 12.37 & 446.0817 & {$[\mathrm{M}+\mathrm{H}]^{+}$} & 447.0890 & 447.0902 & 3.3 & $\mathrm{C}_{21} \mathrm{H}_{18} \mathrm{O}_{11}$ & 271.0591 & $\begin{array}{l}\text { Genistein-O-glucuron- } \\
\text { ide [24] }\end{array}$ \\
\hline 14 & 13.02 & 276.1090 & {$[\mathrm{M}+\mathrm{H}]^{+}$} & 277.1163 & 277.1183 & 0.3 & $\mathrm{C}_{14} \mathrm{H}_{16} \mathrm{~N}_{2} \mathrm{O}_{4}$ & $231.1117,186.0894$ & $\begin{array}{l}\text { N-lactoyl-tryptophan } \\
\text { [21] }\end{array}$ \\
\hline 15 & 13.50 & 210.1348 & {$[\mathrm{M}+\mathrm{H}]^{+}$} & 211.1421 & 211.1441 & 2.4 & $\mathrm{C}_{11} \mathrm{H}_{18} \mathrm{~N}_{2} \mathrm{O}_{2}$ & $138.1272,70.0655$ & $\begin{array}{l}\text { L,L-Cyclo(leucylprolyl) } \\
{[22]}\end{array}$ \\
\hline 16 & 15.03 & 502.1074 & {$[\mathrm{M}+\mathrm{H}]^{+}$} & 503.1147 & 503.1184 & 0.01 & $\mathrm{C}_{24} \mathrm{H}_{22} \mathrm{O}_{12}$ & 255.0631 & $\begin{array}{l}\text { 6"-O-Malonyldaidzin } \\
\text { [24] }\end{array}$ \\
\hline 17 & 15.20 & 432.103 & {$[\mathrm{M}+\mathrm{H}]^{+}$} & 433.1103 & 433.1129 & 2.68 & $\mathrm{C}_{21} \mathrm{H}_{20} \mathrm{O}_{10}$ & 271.0581 & Genistin [23] \\
\hline 18 & 15.74 & 175.0621 & {$[\mathrm{M}+\mathrm{H}]^{+}$} & 176.0730 & 176.0706 & -1.11 & $\mathrm{C}_{10} \mathrm{H}_{9} \mathrm{NO}_{2}$ & 130.0588 & Indoleacetic acid [30] \\
\hline 19 & 17.02 & 458.1188 & {$[\mathrm{M}+\mathrm{H}]^{+}$} & 459.1261 & 459.1286 & 2.34 & $\mathrm{C}_{23} \mathrm{H}_{22} \mathrm{O}_{10}$ & 255.0634 & 6"-O-Acetyldaidzin [24] \\
\hline 20 & 17.28 & 488.1288 & {$[\mathrm{M}+\mathrm{H}]^{+}$} & 489.1361 & 489.1391 & 3.15 & $\mathrm{C}_{24} \mathrm{H}_{24} \mathrm{O}_{11}$ & 285.0737 & 6"-O-Acetylglycitin [24] \\
\hline 21 & 17.91 & 518.1029 & {$[\mathrm{M}+\mathrm{H}]^{+}$} & 519.1102 & 519.1133 & -0.55 & $\mathrm{C}_{24} \mathrm{H}_{22} \mathrm{O}_{13}$ & 271.0584 & 6"-Malnoylgenistin [24] \\
\hline 22 & 18.67 & 145.0527 & {$[\mathrm{M}+\mathrm{H}]^{+}$} & 146.0602 & 146.0621 & 0.28 & $\mathrm{C}_{9} \mathrm{H}_{7} \mathrm{NO}$ & $91.0547,77.0392$ & $\begin{array}{l}\text { 1H-Indole-3-carboxal- } \\
\text { dehyde [31] }\end{array}$ \\
\hline 23 & 20.35 & 474.1146 & {$[\mathrm{M}+\mathrm{H}]^{+}$} & 475.1219 & 475.1235 & 3.35 & $\mathrm{C}_{23} \mathrm{H}_{22} \mathrm{O}_{11}$ & 271.0578 & 6"-O-Acetylgenistin [24] \\
\hline 24 & 21.25 & 254.0563 & {$[\mathrm{M}+\mathrm{H}]^{+}$} & 255.0636 & 255.0652 & 3.24 & $\mathrm{C}_{15} \mathrm{H}_{10} \mathrm{O}_{4}$ & $237.0527,137.0223$ & Daidzein [23] \\
\hline 25 & 21.76 & 284.0666 & {$[\mathrm{M}+\mathrm{H}]^{+}$} & 285.0739 & 285.0757 & 2.51 & $\mathrm{C}_{16} \mathrm{H}_{12} \mathrm{O}_{5}$ & $270.0501,242.0548$ & Glycitein [23] \\
\hline 26 & 25.21 & 515.2909 & {$[\mathrm{M}+\mathrm{H}]^{-}$} & 514.2836 & 514.2844 & 1.55 & $\mathrm{C}_{26} \mathrm{H}_{45} \mathrm{NO}_{7} \mathrm{~S}$ & $\begin{array}{r}353.2490,124.0074 \\
106.9810,80.0027\end{array}$ & Taurocholic acid $[28,29]$ \\
\hline 27 & 26.15 & 465.3094 & {$[\mathrm{M}+\mathrm{H}]^{-}$} & 464.3021 & 464.3018 & -0.73 & $\mathrm{C}_{26} \mathrm{H}_{43} \mathrm{NO}_{6}$ & $\begin{array}{l}435.3073,402.2974 \\
\quad 74.0251\end{array}$ & Glycocholic acid [27] \\
\hline 28 & 26.72 & 270.0511 & {$[\mathrm{M}+\mathrm{H}]^{+}$} & 271.0584 & 271.0601 & 3.29 & $\mathrm{C}_{15} \mathrm{H}_{10} \mathrm{O}_{5}$ & 153.0171 & Genistein [23] \\
\hline 29 & 28.14 & 406.2692 & {$[\mathrm{M}+\mathrm{H}]^{-}$} & 405.2619 & 405.2636 & 3.76 & $\mathrm{C}_{24} \mathrm{H}_{38} \mathrm{O}_{5}$ & $\begin{array}{l}389.2649,371.2541 \\
353.2437\end{array}$ & Oxocholic acid [26] \\
\hline 30 & 30.31 & 499.2969 & {$[\mathrm{M}+\mathrm{H}]^{-}$} & 498.2896 & 498.2895 & -0.24 & $\mathrm{C}_{26} \mathrm{H}_{45} \mathrm{NO}_{6} \mathrm{~S}$ & $\begin{array}{r}480.2758,124.0074 \\
106.9810,80.0027\end{array}$ & $\begin{array}{l}\text { Taurochenodeoxycholic } \\
\text { acid [28] }\end{array}$ \\
\hline 31 & 31.23 & 408.2861 & {$[\mathrm{M}+\mathrm{H}]^{-}$} & 407.2803 & 407.2788 & 3.67 & $\mathrm{C}_{24} \mathrm{H}_{40} \mathrm{O}_{5}$ & $\begin{array}{l}389.2641,343.2629 \\
289.2168\end{array}$ & Cholic acid $[25,26]$ \\
\hline 32 & 32.09 & 449.3138 & {$[\mathrm{M}+\mathrm{H}]^{-}$} & 448.3065 & 448.3068 & 0.77 & $\mathrm{C}_{26} \mathrm{H}_{43} \mathrm{NO}_{5}$ & $\begin{array}{r}405.2652,386.3051 \\
330.2422,74.0251\end{array}$ & $\begin{array}{l}\text { Glycochenodeoxycholic } \\
\text { acid [27] }\end{array}$ \\
\hline 34 & 39.88 & 392.2925 & {$[\mathrm{M}+\mathrm{H}]^{-}$} & 391.2852 & 391.2854 & 0.47 & $\mathrm{C}_{24} \mathrm{H}_{40} \mathrm{O}_{4}$ & 373.2694 & $\begin{array}{l}\text { Chenodeoxycholic acid } \\
{[25,26]}\end{array}$ \\
\hline
\end{tabular}




\section{Bile acids}

ESI-MS/MS spectra in both negative and positive ion modes were examined in this study. According to the fragmentation patterns in negative mode, the BAs could be classified into three groups, namely free Bas, taurineand glycine-conjugated Bas. As shown in Table 1, free BAs were obtained via the neutral losses of $\mathrm{H}_{2} \mathrm{O}$ and $\mathrm{CO}_{2}$ molecules [25]. Compound 31, compound 33 and compound 29 had $m / z^{-} 407.2794,391.2839$ and 405.2619 and the formula were $\mathrm{C}_{24} \mathrm{H}_{40} \mathrm{O}_{5}, \mathrm{C}_{24} \mathrm{H}_{40} \mathrm{O}_{4}$ and $\mathrm{C}_{24} \mathrm{H}_{38} \mathrm{O}_{5}$, respectively. They were cholic acid (CA), chenodeoxycholic acid (CDCA) and oxocholic acid according to the reference and literature [26]. According to the literature [27], the detection of a product ion at $\mathrm{m} / z$ 74 strongly suggested the existence of a glycine moiety at the sidechain terminus. In the case of taurine conjugates, three productions at $m / z 80, m / z 107$, and $m / z 124$ invariably appeared in the product ion spectrum [28]. Compound 26 and compound 30 with $m / z^{-} 514.2865$ and 498.2888 were tended to be taurocholic acid (TCA) and taurochenodesoxychlic acid (TCDCA) and the chemical formula were $\mathrm{C}_{26} \mathrm{H}_{45} \mathrm{NO}_{7} \mathrm{~S}$ and $\mathrm{C}_{26} \mathrm{H}_{45} \mathrm{NO}_{6} \mathrm{~S}$, respectively [29]. Compound 27 and compound 32 with $\mathrm{m} / \mathrm{z}^{-} 464.3010$ and 448.3065 with formula $\mathrm{C}_{26} \mathrm{H}_{43} \mathrm{NO}_{6}$ and $\mathrm{C}_{26} \mathrm{H}_{43} \mathrm{NO}_{5}$ were presumed as glycocholic acid (GCA) and glycochenodeoxycholic acid (GCDCA).

\section{Other compounds}

Compound 18 displayed a protonated molecule at $\mathrm{m} / z 176.0730[\mathrm{M}+\mathrm{H}]^{+}$with the molecular formula $\mathrm{C}_{10} \mathrm{H}_{9} \mathrm{NO}_{2}$, which is consistent with the literature [30], and presumed to be Indoleacetic acid. Compound 22 with formula $\mathrm{C}_{9} \mathrm{H}_{7} \mathrm{NO}$ at $m / z^{+} 146.0602$ was presumed as $1 \mathrm{H}$-indole-3-carboxaldehyde [31].

\section{EAE alleviated the intestinal epithelial barrier dysfunction induced by TNF-a}

The effect of EAE was examined on the paracellular permeability of IEC- 6 cells treated with TNF- $\alpha$. As displayed in Fig. 2a, the TEER of the TNF- $\alpha$-damaged IEC- 6 cell monolayer reduced obviously compared with the control group, showing that TNF- $\alpha$ upregulated the paracellular permeability of the IEC- 6 cell monolayer. By contrast, this decreased TEER was obviously inhibited by co-treatment with EAE. As shown in Fig. 2b, TNF- $\alpha$ increased the FD-4 flux in the IEC- 6 cell monolayer, showing that this inflammatory cytokine increased the paracellular permeability of the IEC-6 cell monolayer. However, this increased FD-4 flux was obviously inhibited by coadministration of EAE. These findings showed that EAE alleviated the TNF- $\alpha$-induced disorder of the intestinal epithelial barrier function.
EAE prevented the TNF-a-induced down-regulated expression of TJ proteins ZO-1 and occludin

In the present study, western blot analysis of $\mathrm{ZO}-1$ and occludin were carried out to investigate the effect of EAE on epithelial barrier-relevant TJ protein expression. As shown in Fig. 2c, d, our results indicated that TNF- $\alpha$ challenge caused an obvious decrease of ZO-1 and occludin protein expressions. However, treatment of the IEC-6 cells with EAE alleviated the TNF- $\alpha$-induced $\mathrm{ZO}-1$ and occludin protein decline.

\section{EAE suppressed the pro-inflammatory cytokines secretion} from TNF- $\alpha$-induced IEC- 6 cells

TNF- $\alpha$ was used to stimulate pro-inflammatory cytokine secretion in IEC- 6 cells to imitate its elevation in some intestinal diseases. As shown in Fig. 2e, f, our results indicated that the levels of IL- 6 and IL- $1 \beta$ in IEC- 6 cells was obviously increased after TNF- $\alpha(50 \mathrm{ng} / \mathrm{mL})$ stimulation. However, treatment of the IEC- 6 cells with EAE $(0.1-0.01 \mathrm{mg} / \mathrm{mL})$ for $24 \mathrm{~h}$ caused an obvious decrease in these pro-inflammatory cytokine levels in a dosedependent manner. These results showed that EAE can regulate the TNF- $\alpha$-induced secretion of pro-inflammatory cytokines.

\section{Anti-inflammatory effects on RAW264.7 cells}

Our results suggested that it had no obvious cytotoxic effects on the RAW264.7 cell when the concentration was lower than $0.1 \mathrm{mg} / \mathrm{mL}$ (Fig. 3a). Then the cell was treated with LPS $(1 \mu \mathrm{g} / \mathrm{mL})$ with/without EAE for $24 \mathrm{~h}$. As in Fig. 3b, the results showed that EAE significantly inhibited LPS-stimulated NO production along with the extract concentrations with $\mathrm{IC}_{50}$ of $18.12 \mu \mathrm{g} / \mathrm{mL}$ (Fig. 3c).

Furthermore, the mRNA expression levels of inflammatory mediators (iNOS and COX-2) and pro-inflammatory cytokines (TNF- $\alpha$, IL- 6 and IL-1 $\beta$ ) were investigated by qRT-PCR. As shown in Fig. 3d-h, a significant reduction in all pro-inflammatory cytokines tested was observed in presence of GGEC as compared to control. In addition, the expression of iNOS and COX-2, was highly and dosedependently down-regulated.

\section{Wound healing assay}

In order to observe the effect of GGEC extract on the restoration of IEC- 6 cells, the cell viability was performed firstly to select the optimal concentrations for further study. As shown in Fig. $4 \mathrm{a}, \mathrm{EAE}$ at $0.1 \mathrm{mg} / \mathrm{mL}$ significantly increased the cell viability (132\%). This result indicated that EAE had a positive effect on cell proliferation. Then the wound healing assay was taken to assess this effect. Compared with the control cells, IEC-6 cells treated with EAE (0.1 and $0.03 \mathrm{mg} / \mathrm{mL})$ showed 
a
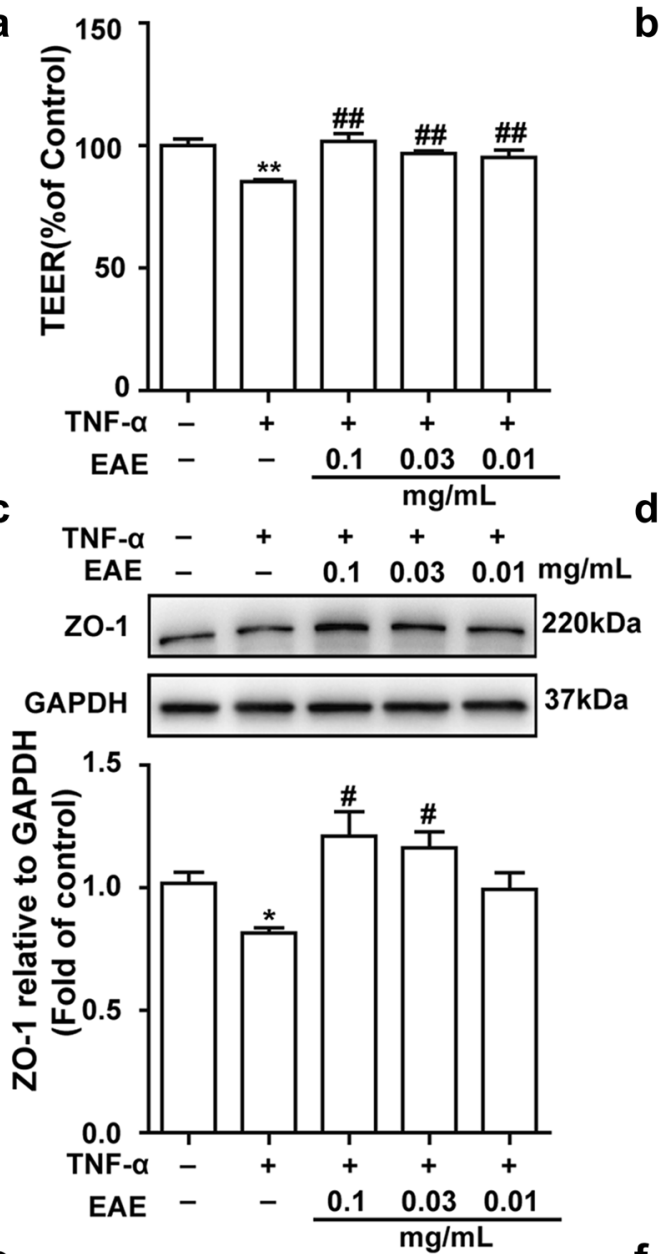

e

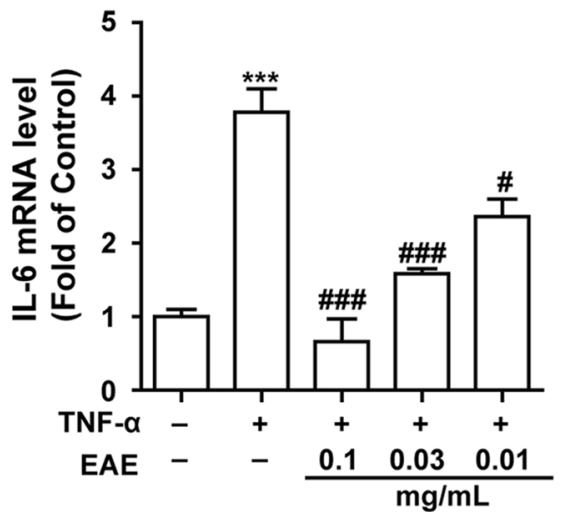

b
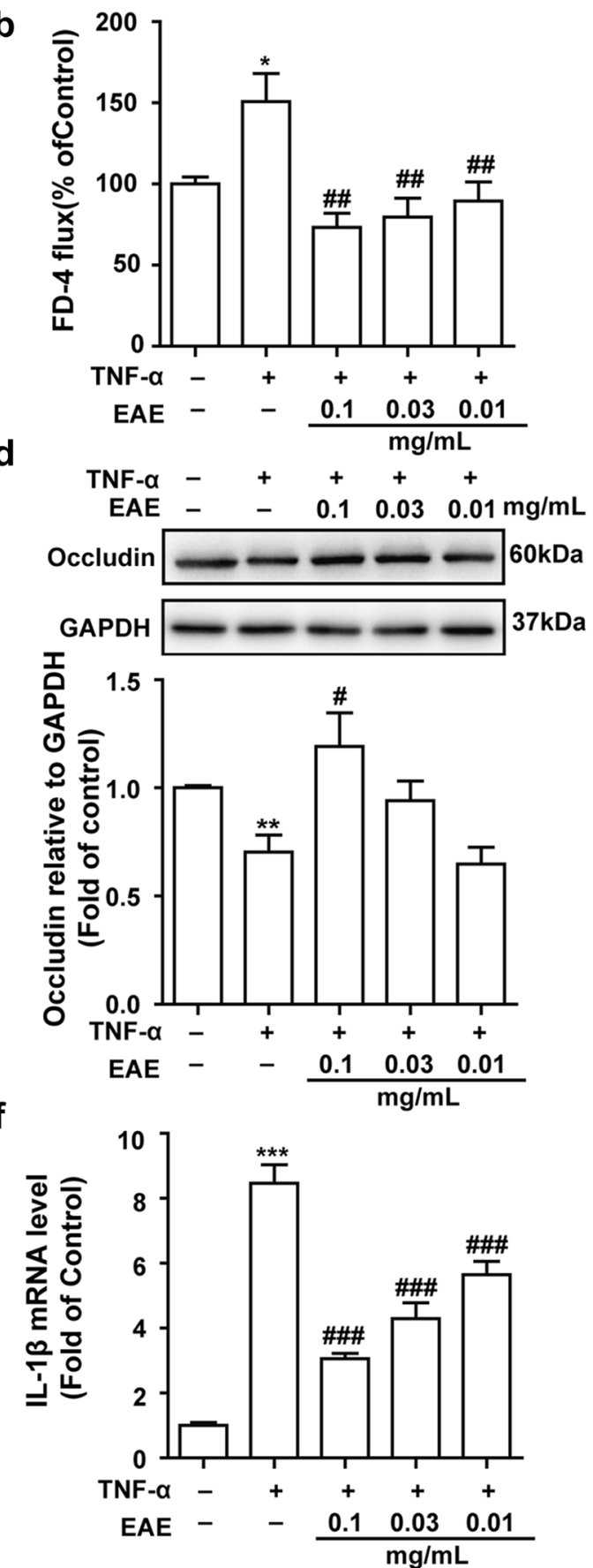

Fig. 2 EAE exerted protective effects on TNF-a-treated IEC-6 cells. When cells reached confluence in the transwell system, Cells were pretreated with $\operatorname{EAE}(0.1,0.03$, and $0.01 \mathrm{mg} / \mathrm{mL})$ for $1 \mathrm{~h}$, followed by TNF-a $(50 \mathrm{ng} / \mathrm{mL})$ stimulation for $24 \mathrm{~h}$. a TEER values were shown as percentage relative to the control. $\mathbf{b}$ Permeability of FD-4 in TNF-a-treated IEC-6 cell. IEC-6 cells were pretreated with EAE $(0.1,0.03$, and $0.01 \mathrm{mg} / \mathrm{mL})$ for $1 \mathrm{~h}$, followed by TNF-a $(50 \mathrm{ng} / \mathrm{mL})$ stimulation for $24 \mathrm{~h}$. The relative ratios of ZO-1/GAPDH and Occludin/GAPDH were calculated based on the densities of bands on Western blots. The protein expression levels of ZO-1 (c) and occludin (d) were increased in TNF-a-treated IEC-6 cells while pretreated with EAE. EAE decreased the mRNA expression levels of IL-6 (e) and IL-1 $\beta(\mathbf{f})$ in TNF- $a$-stimulated IEC- 6 cells. Mean \pm SD $\left(n=3\right.$ independent experiments). ${ }^{*} p<0.05$,

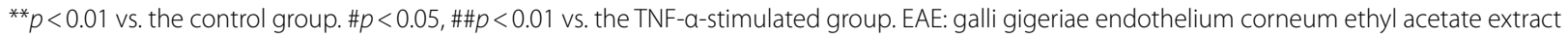




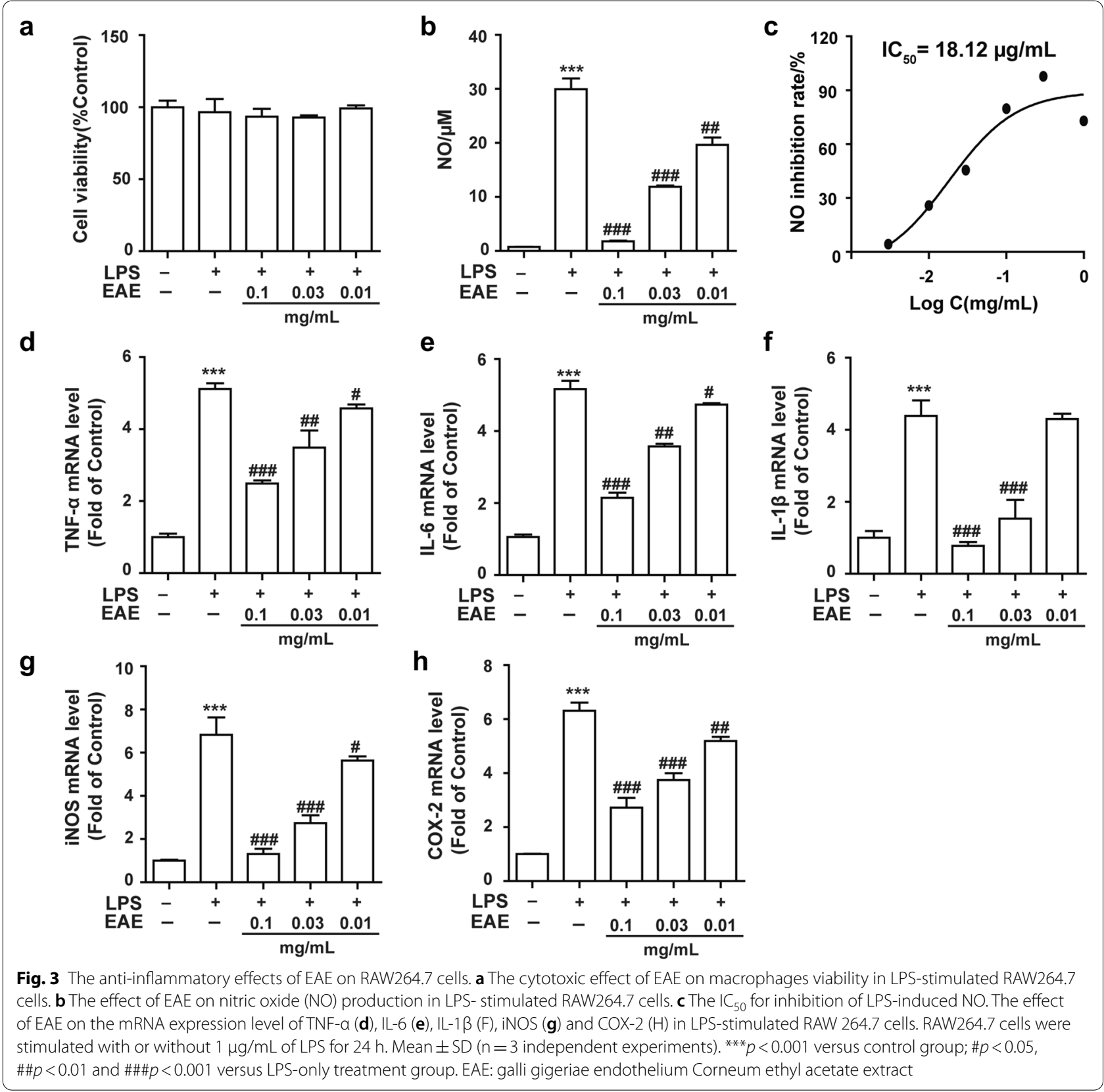

significantly enhanced wound healing after $8 \mathrm{~h}$ of incubation (Fig. 4b, c).

\section{Discussion}

It is well recognized that epithelial cells covering the surface of the gastrointestinal tract are vital to the health functioning as a barrier [32]. The barrier confers a direct property of selective permeability to the intestine $[4,33]$. TJs function as the physical intestinal barrier by regulating the ions, solutes, and water across the intestinal epithelium, protecting against extracellular substances such as antigens, organisms and xenobiotics [5, 12]. Numerous factors such as pro-inflammatory factors, LPS, and bacteria influence TJ homeostasis [34]. It was reported that TNF- $\alpha$ promoted TJ permeability and damaged barrier function due to decrease $\mathrm{ZO}-1$ protein level and activation of the NF- $\mathrm{kB}$ pathway in Caco-2 cells [35]. In this study, we demostrated that EAE alleviated TNF- $\alpha$ induced the reduction of TEER and increase of FD- 4 in paracellular permeability and suppressed the TNF- $\alpha$ evoked down-regulated protein expression of $\mathrm{ZO}-1$ and occludin. 


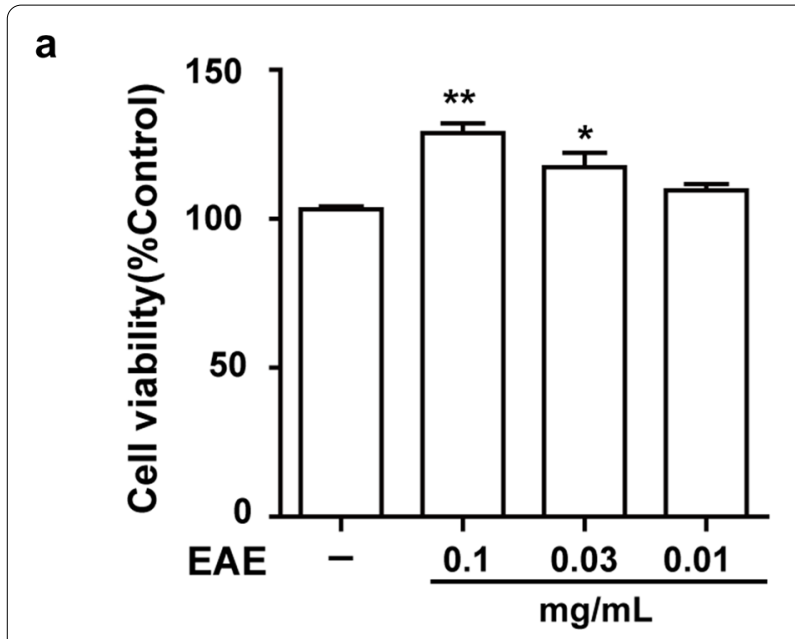

C
$0.1 \mathrm{mg} / \mathrm{mL}$
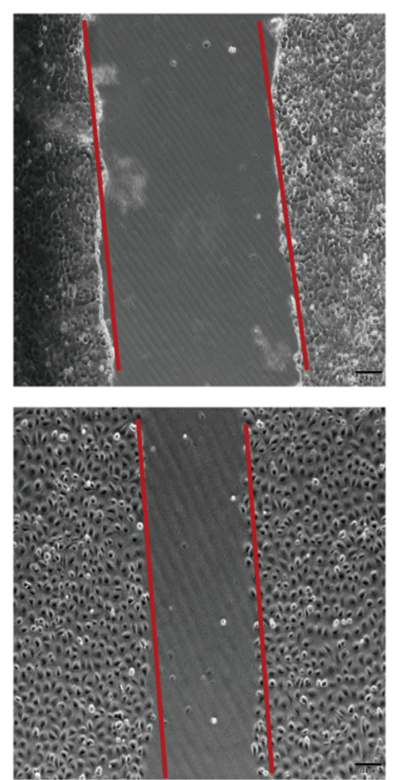

b

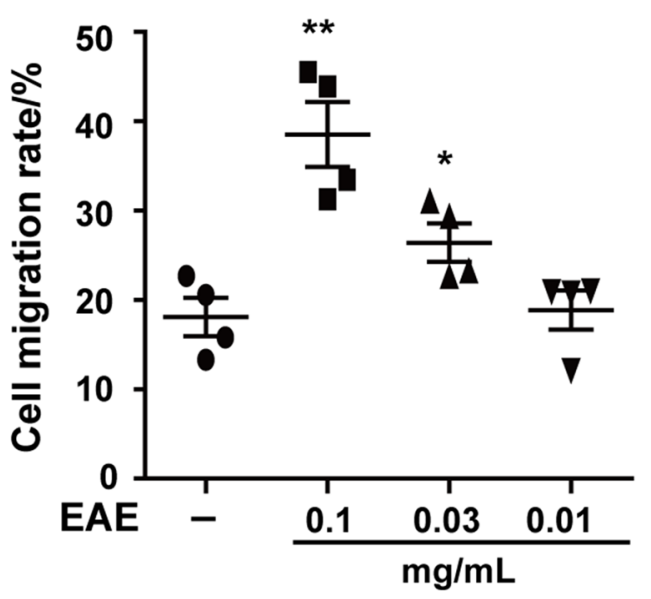

$0.03 \mathrm{mg} / \mathrm{mL}$

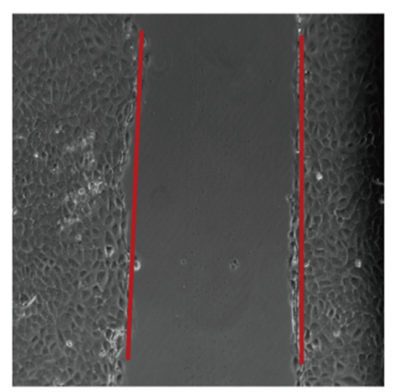

$0.01 \mathrm{mg} / \mathrm{mL}$
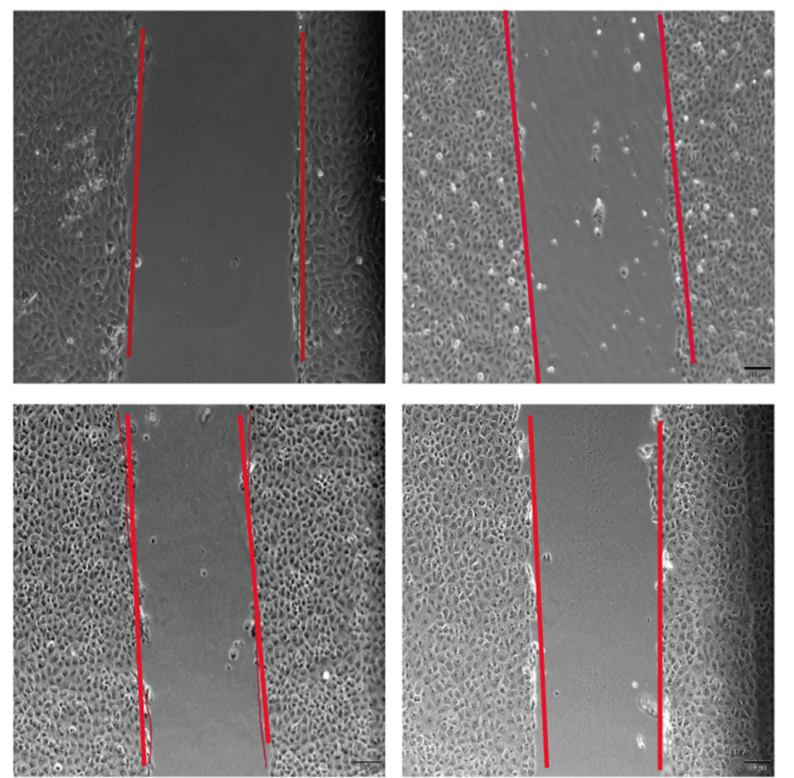

Fig. 4 Effects of EAE on wound healing of IEC-6 cells. a The cytotoxic effect of EAE on cell viability in IEC-6 cells. b Wound healing activity on cell migration of EAE. c The representative image of the wound healing assay. Mean $\pm \mathrm{SD}\left(\mathrm{n}=4\right.$ independent experiments). ${ }^{*} p<0.05$, ${ }^{* *} p<0.01$ vs. the control group. EAE: galli gigeriae endothelium corneum ethyl acetate extract

Inflammatory bowel diseases (IBDs), including ulcerative colitis and Crohn's disease, are well-known recurring and chronic inflammatory conditions of the intestinal epithelial cells $[5,7]$. It was reported that excessive proinflammatory factors may destroy the intestinal barrier function and a dysfunctional barrier facilitated the passage of antigens through the epithelium [36], thereby eliciting an immune response leading to inflammation and subsequently various gastrointestinal disease symptoms [37]. Therefore, inhibition of pro-inflammatory cytokine secretion and improvement of intestinal barrier function are strategies for the prevention and treatment of IBD [38]. In this study, EAE effectively inhibited the mRNA expression of pro-inflammatory cytokines (IL-6 and IL-1 $\beta$ ) in TNF- $\alpha$-stimulated IEC- 6 cells.

In the intestine, a large amount of pro-inflammatory factors was mainly produced by the activated macrophages [37]. Macrophages participate in and promote immune responses by inducing the expression of proinflammatory cytokines (TNF- $\alpha$, IL- 6 , and IL-1 $\beta$ ) when stimulated by the exogenous substances such as LPS. Our results showed that EAE reduced the production 
of pro-inflammatory cytokines (TNF- $\alpha$, IL-6, and IL-1 $\beta$ ) and inflammatory mediators (iNOS and COX-2) in LPSstimulated RAW264.7 cells. The reduction of release of pro-inflammatory cytokines by EAE signified its potential beneficial role in intestinal epithelial barrier function.

It is crucial to retain the integrity of the epithelium for digesting food, absorbing nutrients and preventing harmful external agents from entering the body [5]. When the surface of the intestinal epithelium is damaged, IECs migrate to the injured region and proliferate to maintain homeostasis [35]. Therefore, improving the migration and proliferation of IECs is a promising therapeutic strategy for intestinal disorders [39]. This study aimed to investigate the influence of EAE on the migration and proliferation of IEC- 6 cells. The wound healing assay results showed that treatment of EAE effectively promoted IEC- 6 cells proliferation and migration.

It is reported that GGEC is rich in protein, amino acids and polysaccharide that contributed to its biological activities $[8,10]$. However, the definite constituents still remain unclear. In this work, we explored the compounds in GGEC by HPLC-QTOF-MS/MS. There were 33 compounds including 12 isoflavones, 7 bile acids, 4 nucleic bases and nucleosides as well as 10 others that were systematically identified in EAE. This is the first time that BAs and isoflavones were tentatively identified in GGEC. Some studies suggested that bile acids are important regulators of epithelial integrity and might be the good targets for development of new candidates to modulate intestinal barrier function in diseases treatment [40]. It was reported that BAs, especially chenodeoxycholic acid (CDCA), could protect intestinal epithelial barrier in IPEC-J2 cells and mice via the FXR-MLCK signaling pathway $[41,42]$. Studies have also shown that various flavonoids participate in the regulation of intestinal $\mathrm{TJ}$ barrier integrity [16]. However, whether the bile acids and isoflavones in GGEC were the main constituents that exerted the intestinal barrier protective effects remains further studies.

\section{Conclusions}

In this study, we showed that EAE was mainly composed of isoflavones, cholic acids, amino acids and other molecules. It could ameliorate dysfunction of the intestinal epithelial barrier in IEC- 6 cells via inhibiting the expression of the inflammatory mediators IL- 6 and IL- $1 \beta$, promoting epithelial proliferation and up-regulation of $\mathrm{ZO}-1$ and Occludin protein expression. EAE also significantly reduced LPS-induced NO and mRNA expression levels of TNF- $\alpha$, IL- $1 \beta$, IL- 6 , iNOS and COX-2. The present findings demonstrated that GGEC extract exerted gastrointestinal barrier protective activities via strengthening the link between the cells and limiting inflammatory responses.

\section{Abbreviations}

GGEC: Galli gigeriae endothelium corneum; EAE: GGEC ethyl acetate extract; FD: Functional dyspepsia; IECs: Intestinal epithelial cells; TJs: Tight junctions; IEC-6: Rat intestinal epithelial cells; DMSO: Dimethyl sulfoxide; HPLC-Q-TOFMS: High-performance liquid chromatography coupled with quadrupoletime-of-flight high-definition mass spectrometry; ESI: Electrospray ionization;

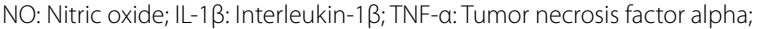
TEER: Transepithelial electrical resistance; iNOS: Inducible nitric oxide synthase; COX-2: Cyclooxygenase-2; FD-4: Fluorescein isothiocyanate-dextran, average mol wt 3000-5000; qRT-PCR: Real-time quantitative reverse transcription polymerase chain reaction; LPS: Lipopolysaccharide; IBDs: Inflammatory bowel diseases; CDCA: Chenodeoxycholic acid.

\section{Acknowledgements}

Not applicable.

\section{Author's contributions}

SL carried out the whole experiments, drafted the manuscript and analyzed the data; MZ carried out the cell experiments; TZ and HP contributed to the interpretation of data of HPLC-QTOF-MS research; WD and JL revised the manuscript. All authors read and approved the final manuscript.

\section{Funding}

This study was supported by the "Double First-Class" University project (CPU2018GY32).

\section{Availability of data and materials}

The research data generated from this study is included within the article.

\section{Ethics approval and consent to participate}

Not applicable.

\section{Consent for publication \\ Not applicable.}

\section{Competing interests}

The authors declare that they have no competing interests.

\section{Author details}

1 Jiangsu Key Laboratory of TCM Evaluation and Translational Research, School of Traditional Chinese Pharmacy, China Pharmaceutical University, Nanjing 211198, People's Republic of China. ${ }^{2}$ State Key Laboratory of Natural Medicines, China Pharmaceutical University, Nanjing 211198, People's Republic of China.

Received: 28 February 2020 Accepted: 6 February 2021

Published online: 16 February 2021
References

1. Jeong SJ, Choi JW, Lee MK, Choi YH, Nam TJ. Spirulina crude protein promotes the migration and proliferation in IEC- 6 cells by activating EGFR/ MAPK signaling pathway. Mar Drugs. 2019;17(4):205.

2. Peron G, Hidalgo-Liberona N, Gonzalez-Dominguez R, Garcia-Aloy M, Guglielmetti S, Bernardi S, Kirkup B, Kroon PA, Cherubini A, Riso P, Andres-Lacueva $C$. Exploring the molecular pathways behind the effects of nutrients and dietary polyphenols on gut microbiota and intestinal permeability: a perspective on the potential of metabolomics and future clinical applications. J Agric Food Chem. 2020;68:1780-9.

3. Omonijo FA, Liu S, Hui Q, Zhang H, Lahaye L, Bodin JC, Gong J, Nyachoti $M$, Yang $C$. Thymol improves barrier function and attenuates inflammatory responses in porcine intestinal epithelial cells during lipopolysaccharide (LPS)-induced inflammation. J Agric Food Chem. 2019;67:615-24. 
4. He C, Deng J, Hu X, Zhou S, Wu J, Xiao D, Darko KO, Huang Y, Tao T, Peng $M$, Wang Z, Yang X. Vitamin A inhibits the action of LPS on the intestinal epithelial barrier function and tight junction proteins. Food Funct. 2019;10:1235-42.

5. lizuka M, Konno S. Wound healing of intestinal epithelial cells. World J Gastroenterol. 2011;17:2161-71.

6. Keita AV, Soderholm JD. Mucosal permeability and mast cells as targets for functional gastrointestinal disorders. Curr Opin Pharmacol. 2018:43:66-71.

7. Bischoff SC, Barbara G, Buurman W, Ockhuizen T, Schulzke JD, Serino M, Tilg H, Watson A, Wells JM. Intestinal permeability—a new target for disease prevention and therapy. BMC Gastroenterol. 2014;14:189.

8. Wang N, Zhang D, Zhang YT, Xu W, Wang YS, Zhong PP, Jia TZ, Xiu YF. Endothelium corneum gigeriae galli extract inhibits calcium oxalate formation and exerts anti-urolithic effects. J Ethnopharmacol. 2019;231:80-9.

9. He Y, Yang C, Wang P, Yang L, Wu H, Liu H, Qi M, Guo Z, Li J, Shi H, Wu X, $\mathrm{Hu} Z$. Child compound endothelium corneum attenuates gastrointestinal dysmotility through regulating the homeostasis of brain-gut-microbiota axis in functional dyspepsia rats. J Ethnopharmacol. 2019;240:111953.

10. Xiong Q, Li X, Zhou R, Hao H, Li S, Jing Y, Zhu C, Zhang Q, Shi Y. Extraction, characterization and antioxidant activities of polysaccharides from $\mathrm{E}$. corneum gigeriae galli. Carbohydr Polym. 2014;108:247-56.

11. Ji R, Wang P, Kou GJ, Zuo XL, Wang X, Li YQ. Impaired gastric mucosal integrity identified by confocal endomicroscopy in Helicobacter pylorinegative functional dyspepsia. Neurogastroenterol Motil. 2020;32:e13719.

12. Chelakkot C, Ghim J, Ryu SH. Mechanisms regulating intestinal barrier integrity and its pathological implications. Exp Mol Med. 2018;50:103.

13. Sarafian MH, Lewis MR, Pechlivanis A, Ralphs S, McPhail MJ, Patel VC, Dumas ME, Holmes E, Nicholson JK. Bile acid profiling and quantification in biofluids using ultra-performance liquid chromatography tandem mass spectrometry. Int J Hyperthermia. 2019;35:112-21.

14. Zhu P, Zhang J, Chen Y, Yin S, Su M, Xie G, Brouwer KLR, Liu C, Lan K, Jia W. Analysis of human C24 bile acids metabolome in serum and urine based on enzyme digestion of conjugated bile acids and LC-MS determination of unconjugated bile acids. Anal Bioanal Chem. 2018;410(21):5287-300.

15. He S, Guo Y, Zhao J, Xu X, Song J, Wang N, Liu Q. Ferulic acid protects against heat stress-induced intestinal epithelial barrier dysfunction in IEC-6 cells via the PI3K/Akt-mediated Nrf2/HO-1 signaling pathway. Int J Hyperthermia. 2019;35(1):112-21.

16. Noda S, Tanabe S, Suzuki T. Differential effects of flavonoids on barrier integrity in human intestinal Caco-2 cells. J Agric Food Chem. 2012;60(18):4628-33.

17. Cheng C, Zou Y, Peng J. Oregano essential oil attenuates RAW264.7 cells from lipopolysaccharide-induced inflammatory response through regulating NADPH oxidase activation-driven oxidative stress. Molecules. 2018;23(8):1857.

18. Gao X, Wei J, Hong L, Fan S, Hu G, Jia J. Comparative analysis of chemical composition, anti-inflammatory activity and antitumor activity in essential oils from siegesbeckiaorientalis, S. glabrescens and S. pubescens with an ITS sequence analysis. Molecules. 2018;23(9):2185.

19. Garcia-Saavedra NM, Barros L, Reis FS, Roriz CL, Alves MJ, García-Hernandez M, Pérez-Rodríguez ML, Sánchez-Mata MDC, Ramírez-Moreno E, Ferreira ICFR. Chemical characterization and biological activities of two varieties of xoconostle fruits Opuntia joconostle F.A.C Weber ex Diguet and Opuntia matudae Scheinvar. Food Funct. 2019;10(6):3181-7.

20. Hall F, Johnson PE, Liceaga A. Effect of enzymatic hydrolysis on bioactive properties and allergenicity of cricket (Gryllodes sigillatus) protein. Food Chem. 2018;262:39-47.

21. Jabeur I, Pereira E, Caleja C, Calhelha RC, Sokovic M, Catarino L, Barros $L$, Ferreira I. Exploring the chemical and bioactive properties of Hibiscus sabdariffa L. calyces from Guinea-Bissau (West Africa). Food Funct. 2019;10(4):2234-43.

22. Choe U, LiY, Gao B, Yu L, Wang TTY, Sun J, Chen P, Yu LL. The chemical composition of a cold-pressed milk thistle seed flour extract, and its potential health beneficial properties. Food Funct. 2019;10(5):2461-70.

23. Prokudina EA, Havličcek L, Al-Maharik N, Lapčík O, Strnad M, Gruz J. Rapid UPLC-ESI-MS/MS method for the analysis of isoflavonoids and other phenylpropanoids. J Food Compos Anal. 2012;26(1-2):36-42.

24. Yan Y, Chai CZ, Wang DW, Wu J, Xiao HH, Huo LX, Zhu DN, Yu BY. Simultaneous determination of puerarin, daidzin, daidzein, paeoniflorin, albiflorin, liquiritin and liquiritigenin in rat plasma and its application to a pharmacokinetic study of Ge-Gen Decoction by a liquid chromatography-electrospray ionization-tandem mass spectrometry. J Pharm Biomed Anal. 2014;95:76-84.

25. Basilicata MG, Pepe G, Adesso S, Ostacolo C, Sala M, Sommella E, Scala MC, Messore A, Autore G, Marzocco S, Campiglia P. Antioxidant properties of buffalo-milk dairy products: a beta-Lg peptide released after gastrointestinal digestion of buffalo ricotta cheese reduces oxidative stress in intestinal epithelial cells. Int J Mol Sci. 2018;19(7):1955.

26. Brophy P, Broeckling CD, Murphy J, Prenni JE. Ion-neutral clustering of bile acids in electrospray ionization across UPLC flow regimes. J Am Soc Mass Spectr. 2018;29(4):651-62.

27. Maekawa M, Shimada M, lida T, Goto J, Mano N. Tandem mass spectrometric characterization of bile acids and steroid conjugates based on low-energy collision-induced dissociation. Steroids. 2014;80:80-91.

28. Mano N, Mori M, Ando M, Goto T, Goto J. Ionization of unconjugated, glycine- and taurine-conjugated bile acids by electrospray ionization mass spectrometry. J Pharm Biomed Anal. 2006;40(5):1231-4.

29. Qiao X, Ye M, Liu CF, Yang WZ, Miao WJ, Dong J, Guo DA. A tandem mass spectrometric study of bile acids: interpretation of fragmentation pathways and differentiation of steroid isomers. Steroids. 2012;77(3):204-11.

30. Zulfiker AHM, Sohrabi M, Qi J, Matthews B, Wei MQ, Grice ID. Multiconstituent identification in Australian cane toad skin extracts using high-performance liquid chromatography high-resolution tandem mass spectrometry. J Pharm Biomed Anal. 2016;129:260-72.

31. Lin GH, Chang CY, Lin HR. Systematic profiling of indole-3-acetic acid biosynthesis in bacteria using LC-MS/MS. J Chromatogr B. 2015;988:53-8.

32. Yang Y, Zhang L, Jiang G, Lei A, Yu Q, Xie J, Chen Y. Evaluation of the protective effects of Ganoderma atrum polysaccharide on acrylamide-induced injury in small intestine tissue of rats. Food Funct. 2019;10(9):5863-72.

33. Shi J, Zhao XH. Effect of caseinate glycation with oligochitosan and transglutaminase on the intestinal barrier function of the tryptic caseinate digest in IEC-6 cells. Food Funct. 2019;10(2):652-64.

34. Bhat AA, Uppada S, Achkar IW, Hashem S, Yadav SK, Shanmugakonar M, Al-Naemi HA, Haris M, Uddin S. Tight junction proteins and signaling pathways in cancer and inflammation: a functional crosstalk. Front Physiol. 1942;2018:9.

35. Groschwitz KR, Hogan SP. Intestinal barrier function: molecular regulation and disease pathogenesis. J Allergy Clin Immunol. 2009;124(1):3-20 (quiz 21-22).

36. Lee B, Moon KM, Kim CY. Tight junction in the intestinal epithelium: its association with diseases and regulation by phytochemicals. J Immunol Res. 2018;2018:2645465.

37. Olejnik A, Kowalska K, Kidon M, Czapski J, Rychlik J, Olkowicz M, Dembczynski R. Purple carrot anthocyanins suppress lipopolysaccharide-induced inflammation in the co-culture of intestinal Caco-2 and macrophage RAW264.7 cells. Food Funct. 2016;7(1):557-64.

38. Li Y, Tian X, Li S, Chang L, Sun P, Lu Y, Yu X, Chen S, Wu Z, Xu Z, Kang W. Total polysaccharides of adlay bran (Coix lachryma-jobi L.) improve TNFalpha induced epithelial barrier dysfunction in Caco-2 cells via inhibition of the inflammatory response. Food Funct. 2019;10(5):2906-13.

39. Uemura T, Yashiro T, Oda R, Shioya N, Nakajima T, Hachisu M, Kobayashi S, Nishiyama C, Arimura Gl. Intestinal anti-inflammatory activity of perillaldehyde. J Agric Food Chem. 2018;66(13):3443-8.

40. Mroz MS, Lajczak NK, Goggins BJ, Keely S, Keely SJ. The bile acids, deoxycholic acid and ursodeoxycholic acid, regulate colonic epithelial wound healing. Am J Physiol-Gastroint Liver Physiol. 2018;314(3):G378-87.

41. Ding $L$, Yang $L$, Wang Z, Huang W. Bile acid nuclear receptor FXR and digestive system diseases. Acta Pharm Sin B. 2015;5(2):135-44.

42. Song $M$, Ye J, Zhang F, Su H, Yang X, He H, Liu F, Zhu X, Wang L, Gao P, Shu G, Jiang Q, Wang S. Chenodeoxycholic acid (CDCA) protects against the lipopolysaccharide-induced impairment of the intestinal epithelial barrier function via the FXR-MLCK pathway. J Agric Food Chem. 2019;67(32):8868-74.

\section{Publisher's Note}

Springer Nature remains neutral with regard to jurisdictional claims in published maps and institutional affiliations. 